\title{
SISTEM PENJERNIHAN AIR LIMBAH PEMOTONGAN BATU LAHAR DI DESA MUNGGU KABUPATEN BADUNG
}

\author{
I K.G. Wirawan ${ }^{1}$, I K.G. Sugita ${ }^{2}$, N.N. Pujianiki ${ }^{3}$, K. Astawa ${ }^{4}$
}

\begin{abstract}
ABSTRAK
Saluran irigasi di desa Munggu banyak dibuat oleh pemerintah Kabupaten Badung maupun masyarakat setempat. Saluran ini sering mengalami pendangkalan karena kurang pemahaman atau pengetahuan masyarakat tentang konsep bak penampungan air limbah sebelum dibuang ke saluran irigasi maupun badan sungai. Pendangkalan saluran irigasi dihasilkan dari pengerajin pemotongan batu lahar yang merupakan salah satu penghasil limbah sedimen. Metode kegiatan dalam pengabdian kepada masyarakat ini adalah (i) membuat bak penampung air kotor, (ii) memberikan gambaran proses penjernihan air kotor menjadi air irigasi dan penerapannya. Sasaran kegiatan pengabdian adalah pengerajin batu lahar, termasuk usaha bersama atau kelompok usaha di pedesaan dengan kondisi manajemen masih bersifat konvensional dan lemah. Kegiatan ini akan sukses apabila melibatkan pemangku kepentingan (stakeholder) di desa Munggu. Pengabdian kepada masyarakat ini menghasilkan produk saluran air buangan/kotor yang berasal dari hasil pemotongan batu lahar mengalir melalui saluran terbuka dengan penampang berbentuk setengah lingkaran. Air tersebut kemudian masuk ke dalam bak penampungan melalui saluran inlet. Dasar dan dinding bak penampung terbuat dari batako tanpa dilakukan proses finishing. Untuk menjaga keamanan, bak penampung ditutupi dengan plat beton. Kotoran batu lahar akan mengendap di bagian bawah dan air di bagian atas bak penampung. Saluran outlet dibuat untuk aliran air jernih yang terbuat dari pipa PVC dengan diameter 4 inchi sebelum dibuang ke saluran irigasi.
\end{abstract}

Kata kunci : pengerajin batu lahar, penjernihan air kotor, saluran irigasi.

\begin{abstract}
Irrigation channels in the village Munggu many made by the government of Badung regency and the local community. These channels often experience silting due to lack of understanding or knowledge of the community about the concept of wastewater storage tanks before being discharged into irrigation channels and river bodies. Irrigation canal degradation is produced from the lava stone cutter who is one of the producers of sedimentary waste. Methods of activity in community service are (i) making sink water container, (ii) giving description of process of purifying dirty water into irrigation water and its application. The target of devotion activities is lava stone craftsman, including joint business or business group in rural area with management condition still conventional and weak. This activity will be successful if it involves the stakeholders in Munggu village. Devotion to this society produces sewage / dirty sewage products derived from lava stone cuts flowing through an open channel with a semicircular cross section. The water then goes into the reservoir through the inlet channel. Base and wall of container tub made of brick without finishing process. To maintain safety, the container tub is covered with a concrete plate. The lava rock droppings will settle at the bottom and the water at the top of the container tub. Outlet channels are made for clear water streams made of PVC pipes with a diameter of 4 inches before being dumped into the irrigation canal.
\end{abstract}

Keywords: lava stone craftsmen, cleansing of dirty water, irrigation channelss.

\footnotetext{
1,2,4 Staf Pengajar Jurusan Teknik Mesin Fakultas Teknik Universitas Udayana, ikgwirawan@ unud.ac.id

${ }^{3}$ Staf Pengajar Jurusan Teknik Sipil Fakultas Teknik Universitas Udayana
} 


\section{PENDAHULUAN}

Kabupaten Badung merupakan salah Kabupaten di Bali yang letak geografisnya diantara $08^{\circ} 14^{\text {' }}$ 20" sampai dengan $08^{\circ} 50^{\prime} 52^{\prime \prime}$ Lintang Selatan dan $115^{\circ} 05^{\prime} 03^{\prime \prime}$ hingga $115^{\circ} 26^{\prime} 51^{\prime \prime}$ Bujur Timur. Luas wilayahnya $418,52 \mathrm{~km}^{2}$ atau sekitar 7,43\% dari daratan pulau Bali. Kabupaten ini terbagi atas 6 (enam) kecamatan administrasi dengan luas wilayah seperti ditunjukkan dalam tabel 1.

Tabel. 1. Luas Wilayah Setiap Kecamatan di Kabupaten Badung

\begin{tabular}{|l|l|l|l|l|}
\hline No & Kecamatan & Luas $\left(\mathbf{K m}^{2}\right)$ & $\begin{array}{l}\text { Persentase } \\
\text { Luas } \\
\text { Wilayah }\end{array}$ & $\begin{array}{l}\text { Persentase } \\
\text { dibandingkan luas } \\
\text { Bali }\end{array}$ \\
\hline \hline 1 & Kuta Selatan & 101.13 & 24.16 & 1.80 \\
2 & Kuta & 17.52 & 4.19 & 0.31 \\
3 & Kuta Utara & 33.86 & 8.09 & 0.60 \\
4 & Mengwi & 82.00 & 19.59 & 1.46 \\
5 & Abiansemal & 69.01 & 16.49 & 1.23 \\
6 & Petang & 115.00 & 27.48 & 2.04 \\
\hline Kabupaten Badung & 418.52 & 100.00 & 7.43 \\
\hline
\end{tabular}

Sumber : Badung Dalam Angka: 2016

Salah satu dari enam kecamatan ini adalah Mengwi, yang terdiri atas 15 desa dan 5 kelurahan. Secara geografis Kecamatan Mengwi terletak antara 08 26 $36^{\prime \prime}$ - 08 $36^{\circ} 16^{\prime \prime}$ Lintang Selatan dan $115^{\circ} 05^{\prime} 55^{\prime \prime}-115^{\circ} 12^{\prime} 20^{\prime \prime}$ Bujur Timur dengan luas wilayah $82 \mathrm{Km}^{2}$ atau sekitar 19,59 persen dari total luas Kabupaten Badung (Kecamatan Mengwi Dalam Angka: 2016). Dari 20 desa/kelurahan yang ada di kecamatan Mengwi, desa Munggu merupakan salah satunya, dengan batas-batas wilayah seperti pada tabel 2 .

Tabel. 2 Batas Wilayah Desa Munggu

\begin{tabular}{|l|l|l|}
\hline Batas & Desa / Kelurahan & Kecamatan \\
\hline Sebelah utara & Desa Cepaka & Kediri Tabanan \\
\hline Sebelah Selatan & Samudra Indonesia & - \\
\hline Sebelah Timur & Desa Tumbak Bayuh & Mengwi \\
\hline Sebelah Barat & Sungai Penet/Desa Buwit & Tabanan \\
\hline
\end{tabular}

(Sumber : Profil Desa Munggu : 2016)

Luas wilayah desa Munggusebesar 549 Ha dan 67,94\% diantaranya berupa tanah pertanian yang seluruhnya menggunakan sistem pengairan setengah teknis [Profil Desa Munggu 2016]. Komoditas padi yang dikembangkan desa Munggu merupakan tanaman padi sawah. Namun, dari waktu ke waktu baik luas tanam, luas panen maupun produksi komoditas padi sawah menunjukkan kecenderungan meningkat.

Dari kepadatan penduduk 1.187 jiwa per $\mathrm{Km}^{2}$, aktifitas penggunaan air untuk kebutuhan rumah tangga dan kegiatan lainnya sangat tinggi. Limbah air buangan dari kegiatan ini biasanya langsung dibuang ke saluran irigasi persawahan sehingga terjadi pencemaran dan pendangkalan saluran irigasi. Salah satu contohnya adalah pembuatan pelinggih dari batu lahar. Proses pembuatannya banyak menggunakan mesin potong dan hasil sampingannya berupa debu. Debu ini akan beterbangan yang menggangu lingkungan dan cara mengatasinya dengan menyemprotkan air ke produk batu lahar. Air limbah hasil semprotan ini dibuang begitu saja sehingga terjadi pendangkalan pada saluran irigasi. Dalam kegiatan Udayana Mengabdi ini kami ingin membuat sistem penjernihan air limbah pemotongan batu lahar sehingga sedimen di saluran irigasi dapat teratasi. 


\section{MATERI DAN METODE}

\subsection{Materi}

Dalam kegiatan ini materi atau bahan yang diperlukan untuk membuat bak penampungan air kotor adalah sebagai berikut :

a. Batako, digunakan untuk pembuatan dinding bak penampun

b. Pasir, sebagai bahan campuran dengan semen untuk perekat

c. Koral, dicampur dengan semen dan pasir untuk membuat bahan beton penutup bak

d. Semen, sebagai bahan perekat

e. Besi beton, sebagai rangka penutup bak

f. Kawat beton, sebagai pengikat rangka besi beton

g. Talang $1 / 2$ lingkaran dengan radius $30 \mathrm{~cm}$, untuk saluran inlet menuju bak penampungan

h. Pipa PVC 4 dim, untuk saluran outlet menuju saluran irigasi

i. Tripleks, sebagai dasar/wadah pembuatan tutup bak

\subsection{Metode}

Untuk memudahkan pekerjaan dibuat galian bak penampung dengan ukuran 1.5 x $1.5 \times 1.5 \mathrm{~m}$ diantara tempat mesin potong dan saluran irigasi. Kemudian dilakukan pemasangan batako pada dinding bak dengan ukuran seperti pada gambar 1 . Saluran inlet bak dibuat lebih tinggi dari outlet, sekitar 5 sampai $10 \mathrm{~cm}$. Proses pengangkatan sedimen dalam bak dilakukan setiap minggu atau bulan, sesuai kebutuhan. Sedimen ini bisa dimanfaakan sebagai tanah urug.

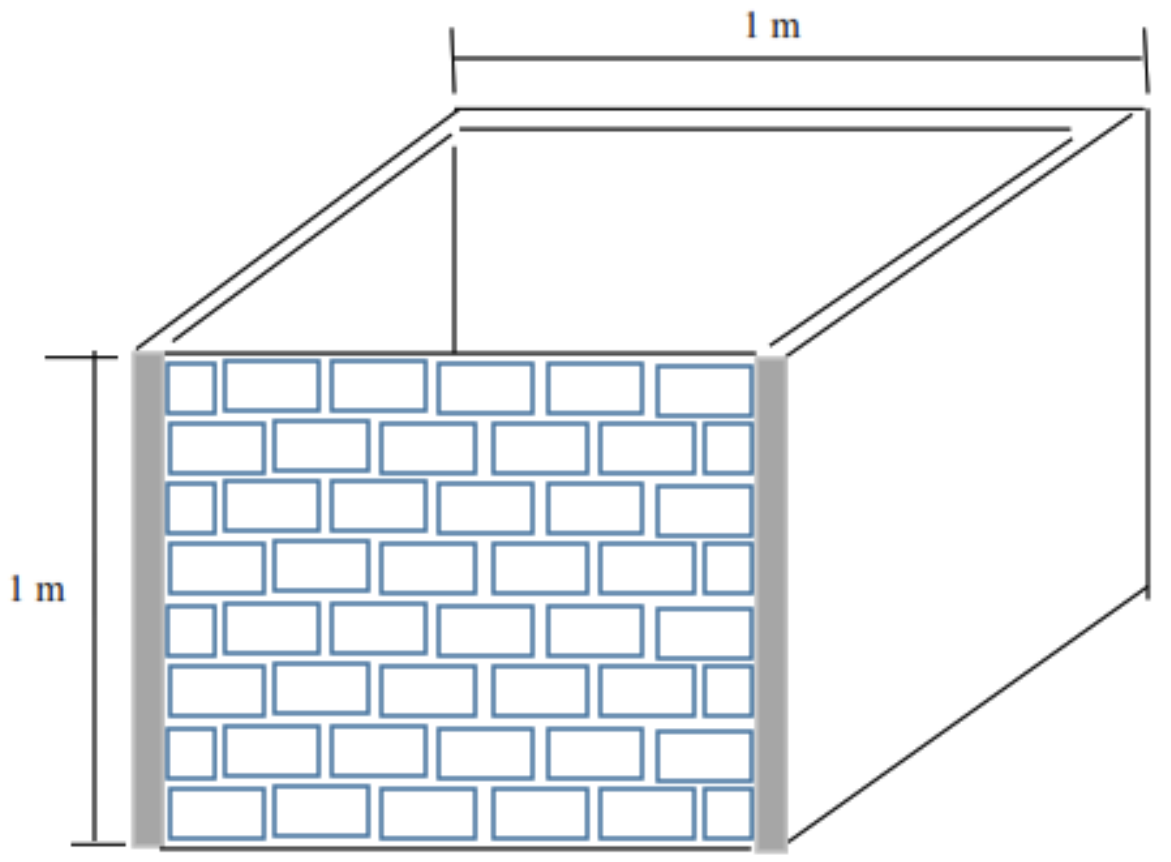

Gambar 1. Bak Penampungan 


\section{HASIL DAN PEMBAHASAN}

Hasil dari kegiatan Udayana Mengabdi di Desa Munggu dapat dilihat pada Gambar 2,3 dan 4.

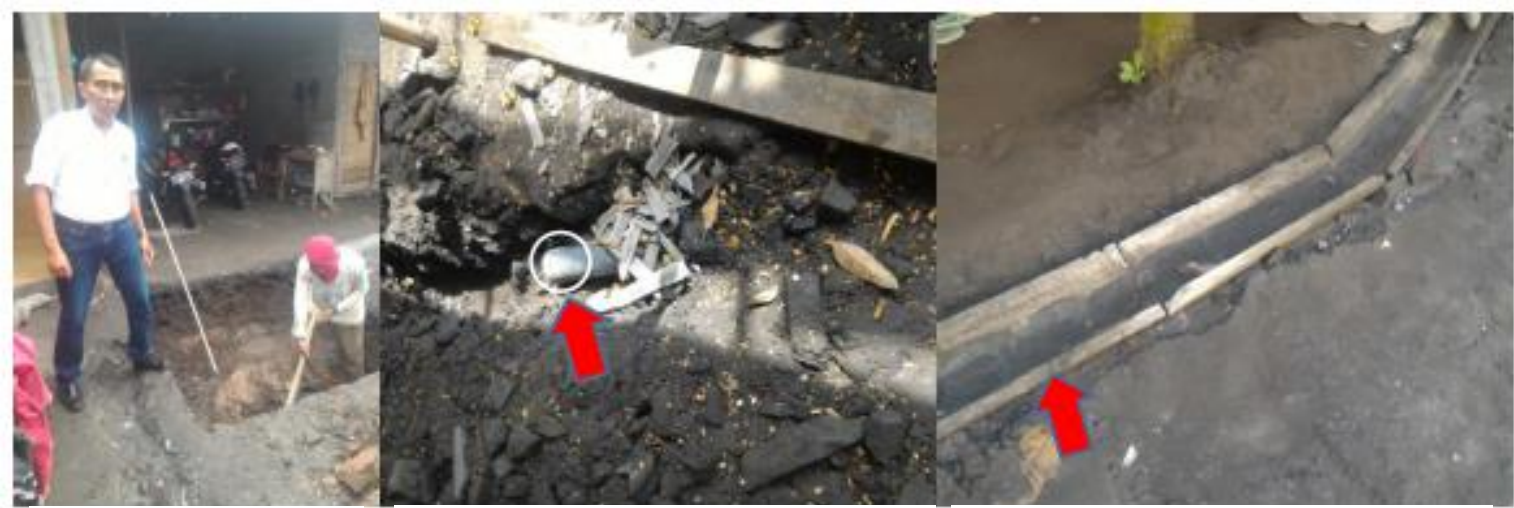

Gambar 2. Galian

Gambar 3. Saluran Outlet

Gambar 4. Saluran Intlet

Bak Penampung

Pengabdian kepada masyarakat di desa Munggu bertujuan memberikan masukan berupa konsep penjernihan air irigasi yang bersumber dari air kotor hasil pemotongan batu lahar seperti ditunjukkan Gambar 5.

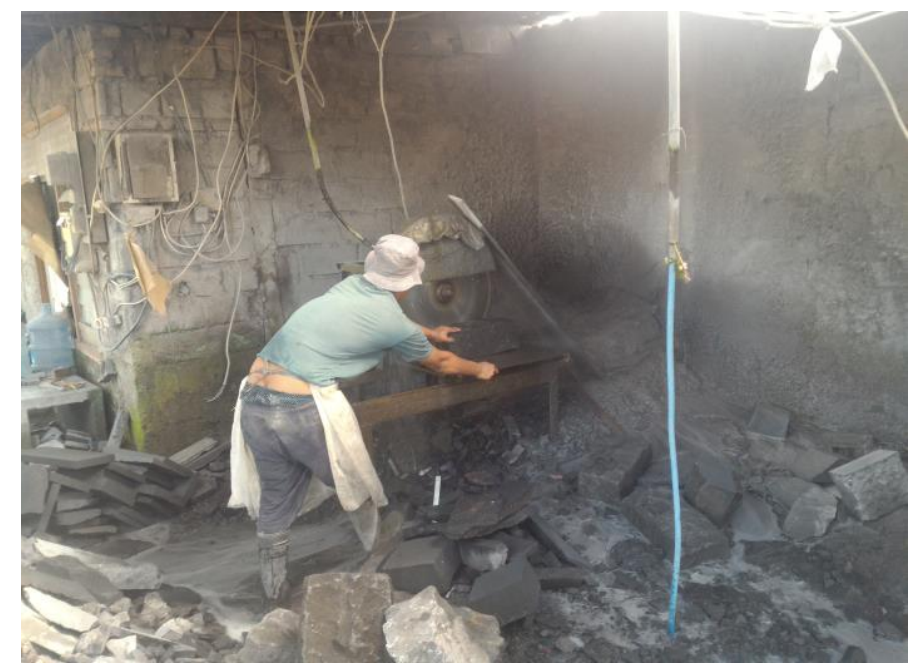

Gambar 5. Proses Pemotongan Batu Lahar

Air kotor hasil pemotongan batu lahar biasanya dibuang ke saluran irigasi. Banyak sekali terdapat serpihan kotoran batu lahar yang akan mengendap di saluran apabila dibiarkan begitu saja. Bak penampungan perlu dibuatkan sehingga air untuk keperluan irigasi pertanian menjadi bersih.

\section{KESIMPULAN DAN SARAN}

\subsection{Kesimpulan}


Air buangan/kotor yang berasal dari hasil pemotongan batu lahar mengalir melalui saluran terbuka dengan penampang berbentuk setengah lingkaran. Air tersebut kemudian masuk ke dalam bak penampungan melalui saluran intake. Dasar dan dinding bak penampung terbuat dari batako tanpa dilakukan proses finishing. Untuk menjaga keamanan, bak penampung ditutupi dengan plat beton. Kotoran batu lahar akan mengendap di bagian bawah dan air di bagian atas bak penampung. Saluran outlet dibuat untuk aliran air jernih yang terbuat dari pipa PVC dengan diameter 4 inchi sebelum dibuang ke saluran irigasi.

\subsection{Saran}

Banyaknya pengerajin Sanggah dimana batu lahar sebagai bahan dasarnya membuat aktifitas pemotongan batu bahar menjadi ramai. Air pendingin mesin pemotong akan menjadi kotor akibat aktifitas ini, sehingga perlu : (i) setiap usaha pengerajin Sanggah harus membuat bak penampung air kotor sebelum dibuang ke badan sungai, (ii) memberikan penyulah kepada operator mesin maupun personal lainnya tentang air bersih.

\section{UCAPAN TERIMAKASIH}

Penulis mengucapkan terimakasih kepada Ketua Lembaga Penelitian dan Pengabdian kepada Masyarakat, Universitas Udayana,yang telah memberikan dana Pengabdian kepada Masyarakat melalui Surat Perjanjian Penugasan Dalam Rangka Pelaksanaan Hibah Pengabdian Kepada Masyarakat Udayana Mengabdi Tahun Anggaran 2017 Nomor : 674 - 20 /UN 14.4.A/PM/ 2017.

\section{DAFTAR PUSTAKA}

Ariyanto, A., 2014. Pengolahan Air Bersih Dilingkungan Kampus Universitas Pasir Pengaraian dengan Sistem Up Flow. Jurnal Mahasiswa Teknik, 1(1).

Asmara, I.W.S., Sujaya, I.N. and Purna, I.N., Faktor-Faktor Yang Mempengaruhi Penggunaan Saringan Sadas Aon Untuk Menyaring Air PDAM di Desa Sukawati Dan Guwang Kec. Sukawati Tahun 2010. Jurnal Skala Husada, p.191.

Artayana, K.C.B. and Atmaja, G.I., 2010. Perencanaan Instalasi Air Bersih dan Air Kotor Pada Bangunan Gedung dengan Menggunakan Sistem Pompa. Jurnal Energi Dan Manufaktur, 4(1).

Air, M.M.P.S.D., Kajian Pemanfaatan Irigasi Air Tanah Pada Sawah Tadah Hujan Tanaman Padi Metode Sri Di Desa Girimukti, Kabupaten Bandung Barat, Provinsi Jawa Barat.

Adi, W., Sari, S.P. and Umroh, S.T., 2015. Efektifitas Filter Bahan Alami Dalam Perbaikan Kualitas Air Masyarakat Nelayan Wilayah Pesisir Kabupaten Bangk. Aquatic, 8(2).

Haliem, W., Juwono, P.T. and Priyantoro, D., 2013. Studi Pola Penatagunaan Potensi Air Sumber Pitu di Wilayah Kali Lajing Sebagai Dasar Pengembangan Sumber Daya Air Wilayah Sungai Amprong. Jurnal Teknik Pengairan, 3(2), pp.230-239.

Purwantoro, D., Pembuatan Pengolah Air Kotor Menjadi Air Bersihpada Daerah Banjir Di Dusun Kalidengen II Temonkulon Progo. INOTEK, 16(2).

Sagala, H.T., Sigit, M. and Hasan, B.D., 2015. Uji Penambahan Media Tanah Pada Saringan Pasir Lambat Pipa (SPL-P) Terhadap Beberapa Parameter Kimia Air Hasil Penyaringan (Doctoral dissertation, Universitas Bengkulu). 